\title{
Molecular Characterization of CMV Infecting Banana from Karnataka Based on Complete Coat Protein Gene Sequence
}

\author{
S. Basavaraj*, K.T. Rangaswamy and M. Bhagyashree
}

Department of Plant Pathology, College of Agriculture, UAS, GKVK, Bangalore-65, Karnataka, India

*Corresponding author

\author{
A B S T R A C T
}

\section{Keywords \\ Cucumber mosaic virus, Banana, \\ Infectious chlorosis, Molecular \\ characterization. \\ Article Info \\ Accepted: \\ 26 September 2017 \\ Available Online: \\ 10 November 2017}

Banana (Musa paradisiaca) is herbaceous plant belonging to the family Musaceae of the genus Musa and is native to the tropical region of South East Asia. Viral diseases have been causing considerable damage to banana production in banana growing areas due to their systemic invasion and common spread through vegetatively propagated planting materials. Among viruses infecting banana Cucumber mosaic virus infecting banana has become more severe and economically important after Banana bunchy top virus (BBTV). Cucumber mosaic virus (CMV) causes infectious chlorosis disease in banana. CMV infecting different crops have been classified into two subgroups (I and II) based on biological and serological properties as well as on the basis of CP sequence homology. Thus, in order to characterize CMV infecting Banana in selected places of Karnataka, complete coat protein gene was amplified and sequenced. The molecular and phylogenetic analysis of $\mathrm{CP}$ gene sequence of CMV infecting banana revealed that CMV infecting Banana in Bangalore, Kolar and Dharwad belongs to Sero group I.

\section{Introduction}

Cucumber mosaic virus (CMV), causing infectious chlorosis disease in banana cultivars, is the most widespread virus after Banana bunchy top virus. Cucumber mosaic virus (CMV), a recognised species under family Bromoviridae and genus Cucumovirus (Roossinck et al., 1999). CMV, transmitted by several species of aphid, is known to infect more than 1000 species of plants in 365 genera of 85 families (Gallitelli 2000). The virion is isometric particle of diameter $29 \mathrm{~nm}$ with three segments of plus sense ssRNAs (RNA 1, RNA 2 and RNA 3) and an additional subgenomic RNA (RNA 4) derived from RNA 3. RNA 1 and RNA 2 encode 1a and 2a proteins, both of which are involved in virus replication (Hayes and Buck 1990). RNA 3 encodes 3a or movement protein (MP) (Shahanavaj Khan et al., 2012) and 3b or coat protein (CP). Several isolates of CMV have been studied and classified into two subgroups (I and II) based on biological and serological properties as well as on the basis of CP sequence homology (Palukaitis et al., 1992; Anderson et al., 1995). The subgroup-I is further divided into IA and IB (Roossinck et al., 1999). The aim of our work was to identify and characterize the causal agent detected in banana plants from Karnataka, collected during survey. Banana is one of the world's most important tropical fruit crop. It is grown both as a staple food and a major 
cash crop. It is propagated vegetatively through suckers. Asia accounts nearly $40 \%$ of world banana production. Bananas grown in South India can be broadly grouped into three types like deserts, culinary and dual purpose varieties. Successful cultivation of banana is varied, because it is influenced by abiotic and biotic factors. Among the biotic factors, several insect and nematode pests and fungal, bacterial and viral pathogens are known to limit the growth and fruit yield of banana (Jeger et al., 1995). Banana is a humid tropic plant coming up with a temperature range of $100 \mathrm{c}$ to $400 \mathrm{c}$ and average of 230c. Four viruses known to naturally infect banana widely in different countries are BBTV, CMV, BBrMV and BSV. Streak symptoms of BSV infection of Musa spp. are sometimes similar to those caused by CMV and the two diseases have been confused (Lockhart et al., 1992). There is a need to detect these viruses for the selection of virus free planting material. Planting of virus free seed or other propagation material is a prime practice for effective disease control.

Banana plants showing typical yellow stripes on leaves as symptoms, in addition to leaf distortion and stunting of plant were collected from different parts of India. The causal agent was identified as Cucumber mosaic virus (CMV) on the basis of transmission electron microscopy and reverse transcription polymerase chain reaction (RT-PCR). Complete coat protein (CP) gene of all isolates were amplified using gene specific primers for coat protein $(\mathrm{CP})$, followed by cloning into desired cloning vector for sequencing. Sequenced region were found containing complete single open reading frame of 657 nucleotides, potentially coding 219 amino acids. Sequence analysis of CP gene showed 93\%-98\% (at nucleotide) and 94\%-99\% (at amino acid) sequence identity between all three Indian isolates. On comparing $\mathrm{CP}$ gene sequences of CMV KAR,
CMV MH and CMV UP with CMV P isolate (Physalis minima); we got 94\%, 99\% and 96\% identity respectively. High degree identity at nucleotide level between these isolates of banana and Physalis minima (a weed) suggest that Physalis minima could be an alternate host of CMV banana. Phylogenetic analysis of nucleotide along with amino acid sequence of coat protein gene revealed that all our isolates belong to IB subgroup. In short, it appears that there occurs a high incidence of CMV infecting banana belonging to IB subgroup in most parts of Indian subcontinent (Shahanavaj Khan et al., 2011).

\section{Materials and Methods}

\section{RNA extraction}

Banana plants showing symptoms of infectious chlorosis (Plate. 1) were collected from important tissue culture growing areas of Karnataka viz., Bangalore, Kolar and Dharwad. Total RNA was extracted from Healthy and CMV infected banana plants using Qiagen plant RNA extraction kit and subsequently used for RT-PCR detection of CMV. Leaf tissue (100-200 mg) was ground to a fine powder in liquid nitrogen in a pestle and mortar and placed in a sterile micro centrifuge tube. The ground tissue was mixed with $1 \mathrm{ml}$ of homogenizing buffer. After incubation at $65^{\circ} \mathrm{C}$ for $10-15 \mathrm{~min}$, two chloroform-isoamyl alcohol (24:1) extractions were performed. RNA was precipitated from the aqueous layer, overnight, at $4^{\circ} \mathrm{C}$ with an equal volume of $4 \mathrm{M}$ lithium chloride. The pellet obtained by centrifugation for 30 min was resuspended in $200 \mu \mathrm{l}$ of TE buffer containing $1 \%$ sodium dodecyl sulfate and incubated at $-20^{\circ} \mathrm{C}$ for 30 min with $100 \mu \mathrm{l}$ of $5 \mathrm{M} \mathrm{NaCl}$ and $300 \mu \mathrm{l}$ of ice-cold Iso-propanol. Following centrifugation for $10 \mathrm{~min}$ the pellet was washed with $70 \%$ ethanol, repelleted, dried 
and dissolved in DEPC water. Stored at $-80^{\circ} \mathrm{C}$ until further use.

\section{Reverse transcription polymerase chain reaction}

RNA from healthy and CMV infected samples was taken for reverse transcription along with positive control (CMV on cucumber) and negative control (distilled water). $20 \mu \mathrm{l}$ RT mixture was prepared by adding the following ingredients into the PCR tube. 5X RT buffer (Supplied with the enzyme) $4 \mu \mathrm{l}, 25 \mathrm{mM} \mathrm{MgCl} 21.0 \mu \mathrm{l}, 10.0$ mMdNTP mixture 2.0 $\mu$ l, Reverse Primer $(10$ $\mu \mathrm{M}) 2.0 \mu \mathrm{l}, M u L v$ Reverse Transcriptase $0.5 \mu \mathrm{l}$ (100 units/ $\mu \mathrm{l})$, Viral RNA 5.0 $\mu \mathrm{l}$, RNAase inhibitor $0.5 \mu \mathrm{l}$ and finally volume was made with sterile distilled water. Reaction mixture containing RNA $(5.0 \mu \mathrm{l})+$ Reverse primer CMVR:5'-AGA GTG GGT

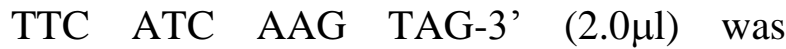
incubated at $74^{\circ} \mathrm{C}$ for 5 minute and then quenched on Ice. Ingredients mixed to this mixture and reverse transcribed at $42^{\circ} \mathrm{C}$ for 45 minute and then at $99^{\circ} \mathrm{C}$ for 5 minute. The c-DNA thus obtained was used for performing PCR.

The c-DNA obtained was subject to PCR amplification using forward primer (CMVF5'-AGA GTG GGT TTC ATC AAG TAG-3') known to amplify a 900 bp product from RNA extracted from CMV infected banana plants which corresponded to the $\mathrm{CP}$ gene of CMV. PCR amplifications were conducted in an thermo-cycler in $25 \mu \mathrm{l}$ reaction mixture that contained $2.0 \mu \mathrm{c}$-DNA, $0.2 \mu \mathrm{l}$ Taq DNA polymerase $(5 \mathrm{U} / \mu \mathrm{l}), 2.5 \mu \mathrm{l}$ of 10X PCR buffer (100 mM Tris- $\mathrm{HCl}, \mathrm{pH}$ $8.3,500 \mathrm{mM} \mathrm{KCl}, 15 \mathrm{mM} \mathrm{MgCl} 2), 0.5 \mu \mathrm{l}$ of $25 \mathrm{mM} \mathrm{MgCl} 2,2.0 \mu \mathrm{l}$ each primer $(10 \mu \mathrm{M})$, $2.0 \mu \mathrm{l}$ dNTPs mix $(2.5 \mathrm{mM}$ each) and sterile water to make up the volume. The mixture was subjected to one cycle of initial Denaturation at $94^{\circ} \mathrm{C}$ for $4 \mathrm{~min}$ followed by
30 cycles of Denaturation at $94^{\circ} \mathrm{C}$ for $30 \mathrm{~S}$, annealing at $53^{\circ} \mathrm{C}$ for $30 \mathrm{~S}$, extension at $72^{\circ} \mathrm{C}$ for $45 \mathrm{~S}$ and a final extension at $72^{\circ} \mathrm{C}$ for 10 min (Shahnawazkhan et al., 2011).

After the completion of the reaction, the products were kept at $4^{\circ} \mathrm{C}$ prior to gel analysis.

\section{Gel electrophoresis and sequencing of PCR products}

Twenty microlitre aliquots from each PCR amplified product were analyzed by 1.0 per cent agarose gel electrophoresis at $60 \mathrm{~V}$ for 1 hr in 1X TBE buffer (Section 3.4.3). The gel was previously stained with ethidium bromide at $0.5 \mu \mathrm{g} / \mathrm{ml}$. The size of the amplification products was estimated from $1 \mathrm{~kb}$ DNA ladder (Gene Ruler TM, Cat. No. SM 0311, Fermentas, GMBH, Germany). PCR amplicons obtained by DNA components using specific primers were separately purified using QIA quick gel extraction kit (Cat. No. 28704; Qiagen, Germany) according to the instructions given by the manufacturer with some modifications. The DNA was eluted in 40-60 $\mu 1$ of elution buffer depending on the initial intensity of the band in agarose gel. The eluted products were stored in $-20^{\circ} \mathrm{C}$ until sent for sequencing bidirectionally with both reverse and forward primers to commercial sequencing service providers viz., Sci Genome sequencing Pvt. Ltd. Kocchi, Kerala.

\section{Sequence analysis of CMV coat protein gene}

The sequences obtained from both CMV forward and CMV reverse reactions were aligned and joined together to get full length sequence using 'nucleotide blast' at basic blast programmes and 'align two (or more) sequences' at specialized blast programmes freely assessing in 'Basic Local Alignment 
Search Tool (BLAST)' at the National Center for Biotechnology Information (http://www.ncbi.nlm.nih.gov/). The complete full-length sequence was subjected to BLAST search. Sequences were compared with other respective viral sequences of the NCBI database using BLAST and multiple aligned using CLUSTALW2 multiple alignment tool (http://www.ebi.ac.uk/Tools/msa/clustalw2/). The phylogenic neighbor-joining trees and evolutionary analysis were conducted using MEGA6.06 software package (Tamura et al., 2007). Robustness of trees was determined by bootstrap sampling of multiple sequence alignment with 1000 replications.

\section{Results and Discussion}

RT-PCR amplification of the CP gene using gene specific primers resulted in the amplification of $\sim 650 \mathrm{bp}$ fragment from banana and cucumber plants infected with CMV but no amplification was observed in healthy samples (Plate 2). The CP specific amplified products were eluted and sequenced. Sequence analysis of $\mathrm{CP}$ gene revealed that the sequenced region contain a single open reading frame, comprised of 657 nucleotides with initiation and termination codon. The sequence identity of CMV infecting banana from Bangalore was 99\% with CMV infecting banana (AM055602) followed by $98 \%$ with CMV isolate AN (AJ810260). Multiple alignment studies of nucleotide CMV-BNG with other reported isolates of CMV from India as well as different parts of the world revealed 90-96\% identity with CMV IA Subgroup strains and $80-85 \%$ identity in nucleotide sequences with the members of subgroup II respectively.

Phylogram constructed using $\mathrm{CP}$ nucleotide alignment of various strains of CMV (IA, IB and II) using MEGA6version 6 revealed that CMV-BNG isolates formed three distinct clusters comprising of CMV IA, IB and II subgroups. Bangalore isolate of banana belong subgroup IB (Figure 1). The CMV isolates used in phylogenetic analysis are listed in Table 1.

Plate. 1a and b Banana plants infected with Cucumber mosaic virus
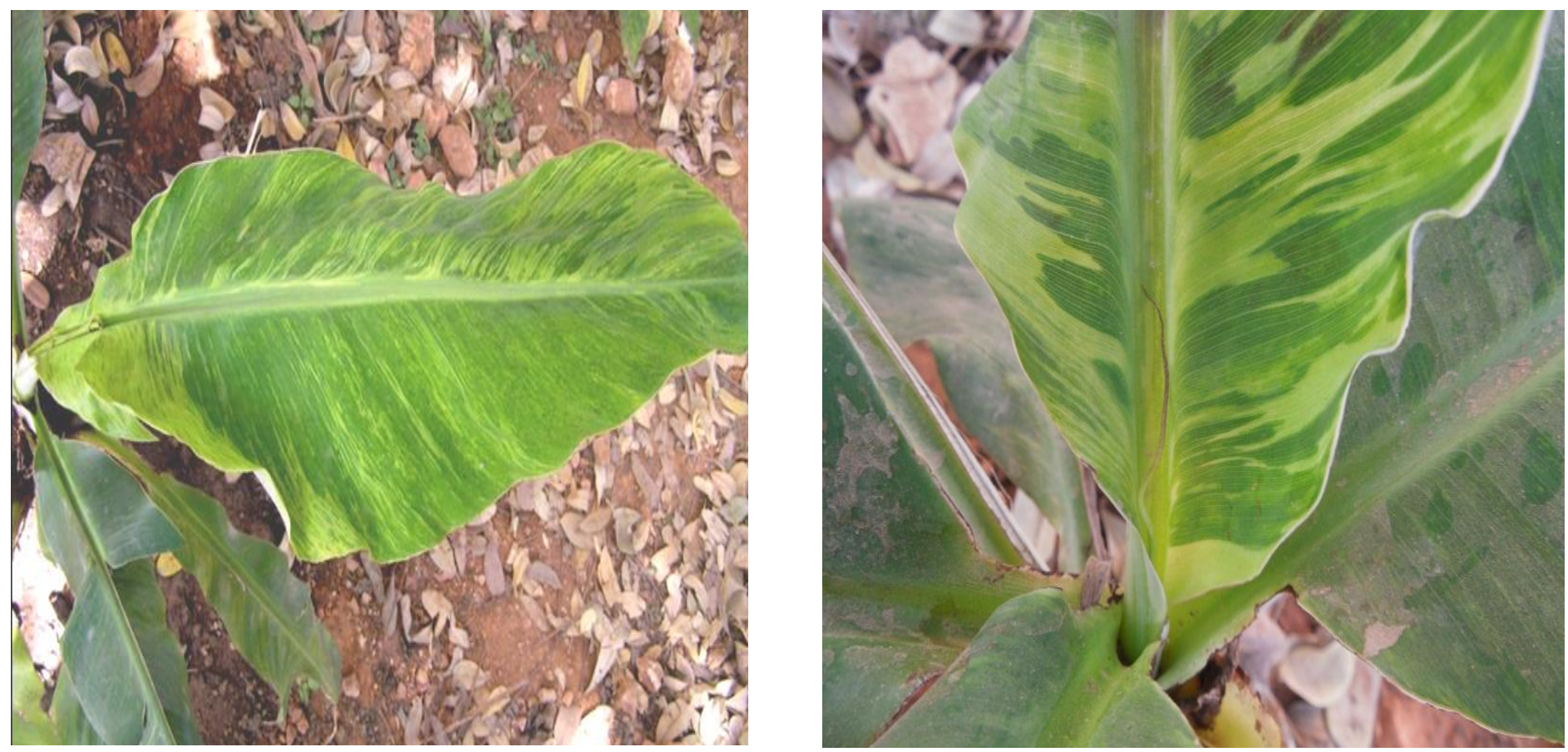
Plate. 2 Gel picture showing amplification of coat protein of CMV through RT-PCR

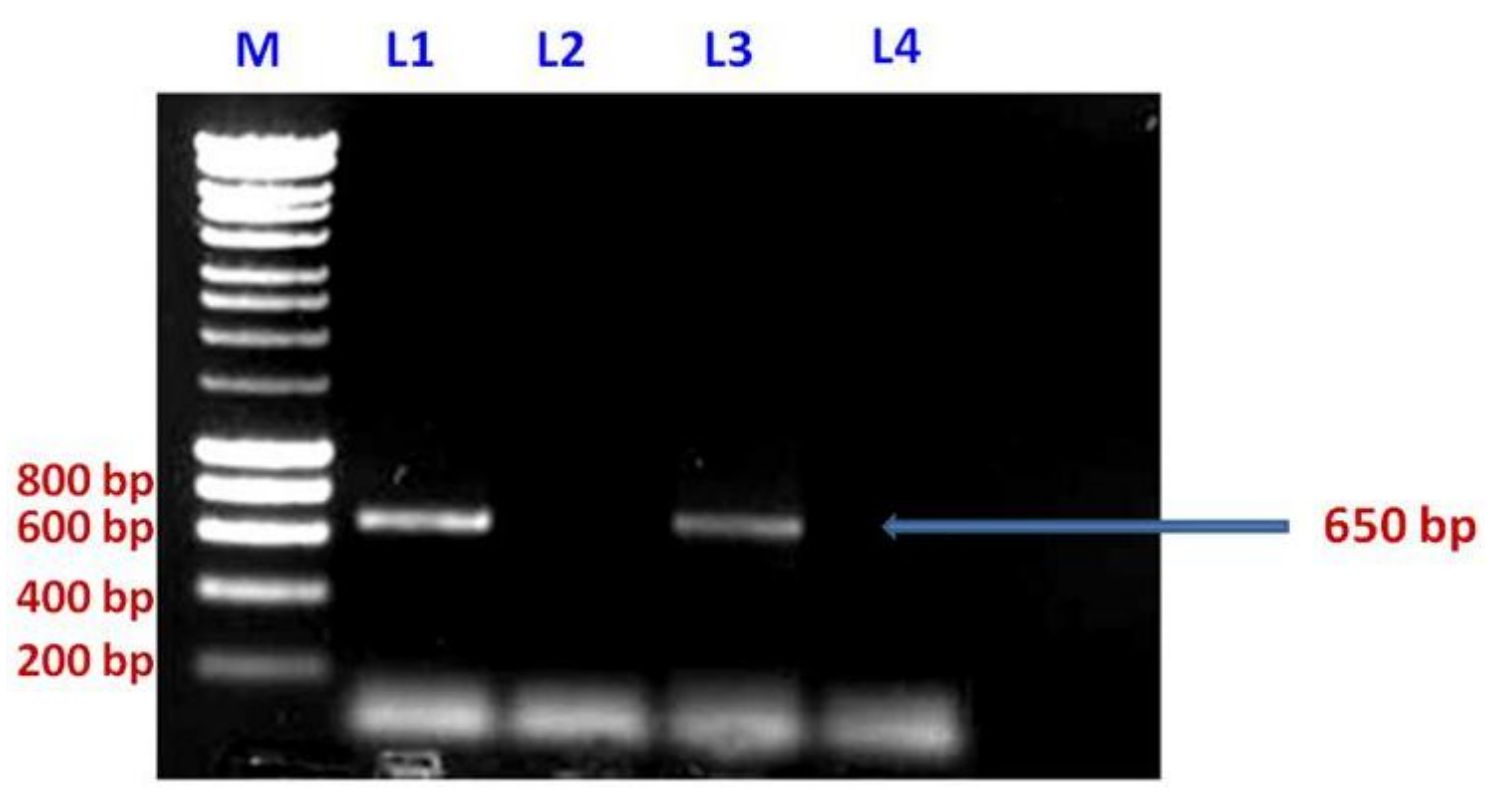

(Legend: Lane M: 200 bp ladder (Bioline), Lane 1: Positive control, Lane2: healthy sample, Lane 3: CMV infected banana and Lane4: water control)

Fig.1 Neighbor hood joining tree showing phylogenetic relationship of CMV infecting banana under present study with CMV infecting other hostsfrom different parts of world based on nucleotide sequence

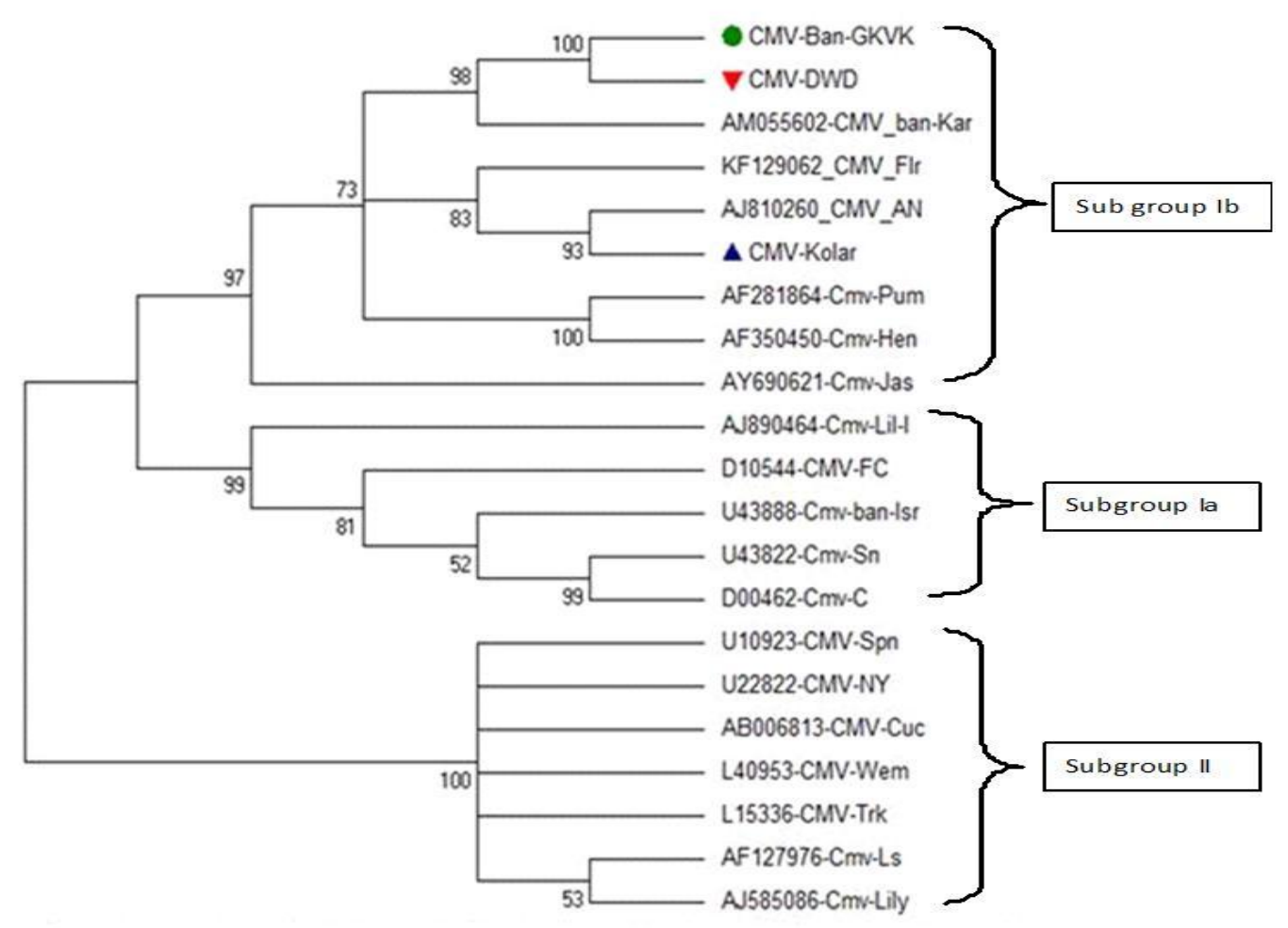


CMV has the broadest host range among the plant viruses and has been reported infecting banana from various parts of the world. Sequence analysis of CMV isolate infecting banana revealed a very high nucleic acid homology with the strains of CMV sub group Ib. Such a high sequence homology of CMVBanana with the CMV subgroupIb strains suggests a common origin of the virus. Also, these results are in contrast with the earlier reports in which Hawaii isolate (Genbank accession number U31219) of CMV banana belong to subgroup IA and China isolate (AF268598) of banana belonging to subgroup II (Shanawaz Khan et al., 2011). These analyses showed that both I and II (A \& B) subgroup of $\mathrm{CMV}$ isolates infecting banana occur in different part of the world.

Since banana is an important fruit crop, it becomes necessary to characterize the virus/es infecting the crop so that effective control measures or quarantine steps can be developed to minimize the losses caused by viruses. Due to high genetic similarity the CMV CP gene can also be used to develop transgenic that will be useful for the growers.

\section{References}

Anderson B J, Boyce P M, Blanchard C L. 1995. RNA4 sequences from cucumber mosaic virus subgroup I and II. Gene. 161:193-194.

Gallitelli D. 2000. Ecology of Cucumber mosaic virus and sustainable agriculture. Virus Res., 71:9-21.

Hayes R J, Buck K W. 1990. Complete replication of a eukaryotic virus RNA in vitro by a purified RNA dependent RNA polymerase. Cell. 63: 363-368.

Jeger M J, Eden-Green S, Thresh J M, Johanson A, Waller J M, Brown A E. Banana diseases In: Bananas and Plantains. Edited by Gowen, S. Published by Chapmann and Hall. 1995:317-381.

Lockhart BEL. Banana streak virus, In: Compendium of tropical plant diseases. 1994; 82: 19-20.

Palukaitis P, Roossinck MJ, Dietzgen RG, Francki RIB. 1992. Cucumber mosaic virus. Adv. Virus Res. 41:281-348.

Roossinck M J, Zhang L and Hellward K 1999 Rearrangements in the 5' nontranslated region and phylogenetic analyses of Cucumber mosaic virus RNA 3 indicate radial evolution of three subgroups; J. Virol. 76 6752-6758.

Shahanavaj Khan, Arif Tasleem Jan, Bikash Mandal, Qazi Mohd and Rizwanul Haq, 2012, Immunodiagnostics of cucumber mosaic virus using antisera developed against recombinant coat protein. Archi. Phytopathol. Pl. Protect, 45(5): 561569.

Shahanavaj Khan, Arif Tasleem Jan, Bushra Aquil, Qazi Mohd. Rizwanul Haq., 2011, Coat Protein Gene Based Characterization Of Cucumber Mosaic Virus Isolates Infecting Banana In India., J. Phytol., 3(2): 94-101.

Tamura, K., Dudley, J., Nei, M. and Kumar, S., 2007, MEGA4: Molecular Evolutionary Genetics Analysis (MEGA) software version 4.0. Mol. Biol. Evol., 24: 1596-1599.

\section{How to cite this article:}

Basavaraj, S., K.T. Rangaswamy and Bhagyashree, M. 2017. Molecular Characterization of CMV Infecting Banana from Karnataka Based on Complete Coat Protein Gene Sequence. Int.J.Curr.Microbiol.App.Sci. 6(11): 3758-3763. doi: https://doi.org/10.20546/ijcmas.2017.611.440 